高分子論文集 (Kobunshi Ronbunshu), Vol. 54, No. 9, pp. 526-536 (Sep., 1997)

\title{
逆相吸着 HPLCによるアセチルセルロースの置換度分布の決定
}

\author{
川井忠智*1 ・寺町信哉*1 ・酒井 貴広*1 ・日比野 剛*1
}

（受付 1997 年 4 月 2 日・審査終了 1997 年 6 月 13 日）

\begin{abstract}
要 旨 本研究においては，逆相吸着 HPLCによりアセチルセルロースの置換度分布（分子間の置換度不均一 性）を決定した. 初めに，HPLCによる置換度分別のための最適条件梌索を行った。種々のカラムと溶離液の組み 合わせを用いて, アセチル化度の異なるアセチルセルロースの組成分別を検討した．その結果，フェニル基修飾シ リカゲルを充填したカラムを用いたアセトン/水：メタノール=3:1の逆相グラシェント溶出が最もよい結果を与 えることを見いだした。次に，この分䧿系を用いて固換度分布の決定を試みた。アアセチルセルロースは柴外部に吸 収をあたないため, 検出器には, エバポレイティブ光散乱検出器を用いた。この検出器は, 実験条件によりレスポ ンスが変化するので，クロマトグラムを定量化するための検量を行い，回㷌計算により置換度分布曲線を得た．得 られた置換度分布曲線から，高置换度の試料ほど分布が狭く，置換度 1.5 に近い試料ほど広い分布をるつことが示 された.
\end{abstract}

\section{1 藸言}

高分子物質の材料としての特性は，その分子特性に大 きく依存する．近年, 環境・資源問題との関連でその重 要性を見直されているセルロース誘導体の分子特性は, 分子量分布の他にも，多くの分子的多分散性，不均一性 をあっている. 中であ置換度 (degree of substitution, DS）に関しては，その平均値（全置換度）のみならず 置換基の分布がその物理的化学的特性に大きな影響を与 えることが知られるようになってきだ),2). この置換基 の分布は, 三つの観点から整理できる.すなおち，(1) グルコースユニット内に存在する三つの水酸基に対する 置換基の分布，(2) 分子鎖内における置換グルコースュ ニットの配列分布, (3) 分子間の $D S$ の分布, である.

（1）は，C-2 位，C-3 位，C-6 位の各水酸基が，どれだ け置換されているか，ということである. グルコースュ ニットは, 3 置換体 1 種, 2 置換体 3 種 (C-2, 3, C-3, 6, $\mathrm{C}-2,6), 1$ 置換体 3 種 (C-2, C-3, C-6), 0 置換体 1 種, の計 8 種の存在が可能である.これらは, 反応条件によ り各々の水酸基の反応性が異なるために生じる. 近年, このグルコースユニット内分布に関しては，NMRによ り解析されている(1),2) S).

(2) は，DS の異なるグルコースユニットが，分子鎖 内でどのように配列しているかという問題である。 セル ロース誘導体を異なるグルコースユニットから成る多元

*1 工学院大学工学部応用化学科（192 東京都八王子市中野 町 2665-1)
共重合体と見なしたとき，これは，合成の統計共重合体 におけるシークエンス分布に相当し，ビニル系共重合体 においては, NMRにより解析されている. しかし, セ ルロース誘導体に関しては, その置換基が離れた位置に あるため, 解析は困難である.

(3)について, 上述したようにセルロース誘導体は, $D S$ の異なる多数の単量体からなる多元共重合体と考え ることもできるが，一方，個々の分子の平均の DS を考 えた場合, 水素結合能を持つ未置換水酸基が多い分子, すなわち DS の低い分子ほど極性が高く，DS の高いも のほど極性が低い分子と考えることができる．よって， それを個々の分子の特性と考えてあ良い。ある一塊の試 料中では, 1 本 1 本の分子ごとに平均の $D S$ は異なって おり, 分子間の置換度不均一性 (多分散性) があること になる。これは, ちょうど, 合成共重合体の化学組成分 布と同様な意味において, 置換度分布ということができ る. 本報告では, 置換度分布を化学組成分布の意味で使 用することとする.

セルロース誘導体の置換度分布に関しては, 古くから 関心があたれているあのの，報告は少ない. Rosenthal とWhiteは, 溶液の相分離現象を利用したアセチルセ ルロースのクロス分別を報告し6)，Kamide らは，薄層 クロマトグラフィーによるアセチルセルロースと二トロ セルロースの置換度分別を報告している7 9). また,

Floyd は, 高性能液体クロマトグラフィー (highperformance liquid chromatography, HPLC) を用いたア セチルセルロースの組成分別を報告しているが，そのク ロマトグラムの定量的な置換度分布への变換は行ってい 
ない10)

従来, 我々は統計共重合体やグラフト共重合体の組成 分別ならびに組成分布の決定に吸着モードのグラジェン 卜HPLC が有効であることを報告してきだ11) 16)，すな わち, 吸着モードの HPLCにおいては, ある程度以上 分子量が大きくなれば, 分離に与える分子量の影響は無 視することができ，組成のみにより分離できる ${ }^{12}$. 我々 は，この方法をセルロース誘導体に適用し，逆相モード の吸着 HPLCを用いてアセチルセルロースの分子間の 置換度分布を決定したので報告する。

\section{2 実匳}

\section{1 試料}

アセチルセルロース試料は,タイセル化学より購入 し，精製して使用した．なお，この試料は，セルロース の水酸基を完全に置換したトリアセチルセルロースか ら, 均一系加水分解により脱アセチル化し, 種々の DS に調整したものである. Table 1 に示した $D S$ は, 滴定 法により決定した ${ }^{17)}$.

\section{2 初濁点}

HPLCにおける分離機構の考察のために，初濁点測 定を行った. 方法は, 試料浱度 $1.0 \mathrm{mg} / \mathrm{cm}^{3}$ で良溶媒に 溶汃した溶液に負溶媒を加えていき，目視にて濁りを判

Table 1. Acetyl cellulose samples

\begin{tabular}{|c|c|c|}
\hline $\begin{array}{l}\text { Sample } \\
\text { code }\end{array}$ & $\begin{array}{c}\text { Degree of } \\
\text { substitution }\end{array}$ & $M_{p} \times 10^{-5 b)}$ \\
\hline CA-44 & 1.75 & \\
\hline CA-51 & 2.18 & 1.54 \\
\hline CA-54 & 2.34 & 1.26 \\
\hline CA-55 & 2.40 & 1.37 \\
\hline CA-61 & 2.84 & \\
\hline CA-62 & 2.92 & \\
\hline$F-1^{c)}$ & 2.40 & 5.73 \\
\hline$F-2^{c)}$ & 2.40 & 2.00 \\
\hline F-3c) & 2.40 & 0.56 \\
\hline
\end{tabular}

a) Determined by titration method. b) Peak molecular weights estimated by SEC (polystyrene standards). c) Fractions of CA-55 sample by SEC.
定した.

\subsection{SEC}

試料の分子量を見積もるためと，吸着 HPLCにおけ る分子量依存性の検討のために，サイズ排除クロマトグ ラフィー(SEC)を使用した. 使用した装置は, CCPE 型ポンプ (東ソー(株)製) と, CO-8000型カラムオー ブン (東ソー(株) 製), UV8011 型紫外可視分光検出器 (東ソ一-(株) 製), RI-8 示差屈折検出器 (東ソー (株) 製)，カラム TSK-gel GMHHR-M (東ソー(株) 製) で 構成されたものである. 測定条件は, カラム温度 $30^{\circ} \mathrm{C}$, 流速 $1.0 \mathrm{~cm}^{3} / \mathrm{min}$, 溶離液にテトラヒドロフラン (THF), 試料濃度 $1.0 \mathrm{mg} / \mathrm{cm}^{3}$, 注入体積 $0.1 \mathrm{~cm}^{3}$, 標準 試料はポリスチレン（東ソー(株)製）を使用した。

\subsection{HPLC}

使用した HPLC の機器は, 2 台の 510 型ポンプ（ウ オーターズ社製)，680型グラジェントコントローラ (ウオーターズ社製)，カラムオーブン（ウオーターズ社 製）から構成される高圧グラジェントシステムである。 測定条件は, カラム温度 $30^{\circ} \mathrm{C}$, 流速 $0.8 \mathrm{~cm}^{3} / \mathrm{min}$, 試料 濃度 $0.01 \sim 1.0 \mathrm{mg} / \mathrm{cm}^{3}$, 注入体積 $0.1 \mathrm{~cm}^{3}$ である. 用い た分離カラムは Table 2 に示した。溶離液の組み合わせ は, 高極性溶媒として, メタノール, エタノール, 水と メタノールの定組成混合物を用い，低（中）極性溶媒と して, アセトン, THF, 酢酸メチル, 塩化メチレンな どを使用した。ここうらの組み合わせを Table 3 に示し た．溶出は，高極性溶媒加ら低（中）極性溶媒へ，直線 的に組成を変化させる直線グラジェントで行った。

なお，検出器には，バレックス社製 Mk II 型エバポ レイティブ光散乱検出器 (evaporative light-scattering detector, ELSD) を用いた. 検出器の蒸発チューブ温度は, 使用した溶離液の組み合わせにより $120.0^{\circ} \mathrm{C}$ から $160.0^{\circ} \mathrm{C}$ の間の定温に設定し,ガス圧は $35 \mathrm{psi}(2.46 \times$ $105 \mathrm{~Pa}$ ), 検出器の attenuation range は 1 から 5 , recorder range は $20 \mathrm{~mA}$ で行った. 置換度分布を決定すると きは,アセトン/水：メタノール $=3: 1$ の溶離液の組み 合わせで, 次のグラジェントプログラムを用いた.

Table 2. Columns used for HPLC

\begin{tabular}{llcccl}
\hline \hline Code & $\begin{array}{c}\text { Chemical bonded } \\
\text { phase }\end{array}$ & $\begin{array}{c}\text { Pore diameter } \\
(\AA)\end{array}$ & $\begin{array}{c}\text { Particle diameter } \\
(\mu \mathrm{m})\end{array}$ & Column size & \multicolumn{1}{c}{ Name } \\
\hline $\mathrm{C} 1$ & Trimethylsilane & 70 & 5 & $4.6 \phi \times 250 \mathrm{~mm}$ & ZORBAX (DUPONT) \\
$\mathrm{C} 4$ & Butyl group & 100 & 5 & $3.9 \phi \times 150 \mathrm{~mm}$ & $\mu$-BONDASHERE (Waters) \\
Ph & Phenyl group & 100 & 5 & $3.9 \phi \times 150 \mathrm{~mm}$ & $\mu$-BONDASHERE (Waters) \\
ODS & Octadecyl group & 80 & 5 & $4.6 \phi \times 150 \mathrm{~mm}$ & Senshu Pack (Senshu) \\
ODP & Octadecyl group & 50 & 6 & $4.6 \phi \times 150 \mathrm{~mm}$ & Asahipak (Asahi Chem.) \\
\hline
\end{tabular}


川井・寺町・酒井・日比野

Table 3. Eluent combinations for HPLC and results of the tubidimetric titration

\begin{tabular}{|c|c|c|c|c|c|c|c|}
\hline \multirow{2}{*}{$\begin{array}{l}\text { Low-polar eluent } \\
\text { (Good solvent) }\end{array}$} & \multirow{2}{*}{$\begin{array}{l}\text { High-polar eluent } \\
\text { (Poor solvent) }\end{array}$} & \multicolumn{6}{|c|}{ Results of tubidimetric titration (poor solvent vol\%) } \\
\hline & & CA-44 & CA-51 & CA-54 & CA-55 & CA-61 & CA-62 \\
\hline Acetone & Water : Methanol = $1: 1$ & 81.9 & 71.4 & 66.2 & 65.4 & - & 一 \\
\hline Acetone & Water : Methanol $=2: 1$ & 75.1 & 64.6 & 61.0 & 53.8 & - & - \\
\hline Acetone & Water : Methanol = $3: 1$ & 74.0 & 53.6 & 51.7 & 50.4 & - & - \\
\hline Acetone & Water : Methanol $=4: 1$ & 68.8 & 53.9 & 46.9 & 53.9 & - & - \\
\hline THF & Methanol & 74.9 & 68.1 & 68.1 & 67.9 & & \\
\hline THF & Water : Methanol = $1: 1$ & 78.7 & 66.6 & 60.9 & 60.4 & - & - \\
\hline THF & Water : Methanol $=2: 1$ & 71.7 & 58.0 & 52.4 & 52.3 & - & - \\
\hline THF & Water : Methanol $=3: 1$ & 68.2 & 52.8 & 48.3 & 48.2 & - & - \\
\hline THF & Water : Methanol $=4: 1$ & 63.6 & 49.5 & 45.6 & 45.5 & - & - \\
\hline THF & Water & - & 39.9 & 39.7 & 36.9 & - & - \\
\hline Ethylene chloride & Ethanol & 70.4 & 63.4 & 63.3 & 64.4 & - & - \\
\hline Methylene chloride & Methanol & 77.4 & 76.3 & 74.3 & 74.2 & 64.1 & 63.2 \\
\hline Methyl acetate & Methanol & 71.7 & 71.4 & 70.2 & 70.2 & - & - \\
\hline Methyl acetate & Water: Methanol $=2: 1$ & 70.4 & 52.9 & 47.7 & 47.4 & - & - \\
\hline Methyl acetate & Water : Methanol $=3: 1$ & 63.3 & 47.2 & 42.9 & 42.9 & - & - \\
\hline Methyl acetate & Water : Methanol $=4: 1$ & 60.2 & 43.1 & 42.4 & 41.2 & - & - \\
\hline
\end{tabular}

\begin{tabular}{lccccccc}
\hline Time (min) & 0 & 4 & 5 & 20 & 21 & 40 & 50 \\
Acetone (vol\%) & 0 & 0 & 30 & 80 & 100 & 100 & 0 \\
\hline
\end{tabular}

\section{3 桔果と考察}

\section{1 試料}

本研究で用いた試料を Table 1 に示した. ここで $M_{\mathrm{p}}$ はSECクロマトグラムのピークトップから見積もった ポリスチレン換算分子量である. また, F-1, F-2, F-3 は, CA-55を SECにより分取した各分画である. 組成 はほぼ等しく分子量的には異なる分画が得られたことか ら，後に示す吸着 HPLCにおける分子量依存性実験に 使用した。

また，吸着 HPLCによる置換度分布決定に用いた CA-51, CA-54, CA-55 の SECクロマトグラムを Fig. 1 に示す.これらから，分子量と分子量分布はほぼ等しい ことが確認された.

\section{2 カラムと溶滩派}

アセチルセルロース試料をその DSにより分離し，置 換度分布を決定するために適したカラムと溶離液の組み 合わせを決めるために行った実験結果を，以下に記述す る.

a. Ph カラムとアセトン/水 : メタノール系による組 成分別

フェニル基修飾シリカゲルを充填したカラム（Ph力 ラム）とアセトン/水：メタノール系のグラジェント溶 出において高極性溶媒の水：メタノール混合液の水の比

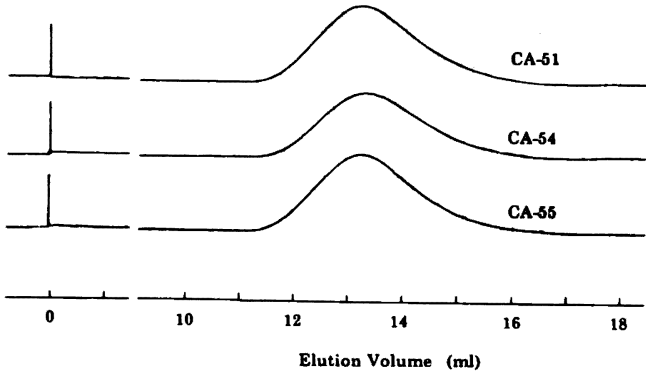

Fig. 1. SEC Chromatograms of CA-51, CA-54, CA55. Column. TSKgel GMHHR-M $7.8 \times 300 \mathrm{~mm}$; eluent, tetrahydrofuran (THF); flow ratio, $1.0 \mathrm{~cm}^{3}$ / min; injection volume, $100 \mu l$; sample concentration, $1.0 \mathrm{mg} / \mathrm{cm}^{3}$.

率を変化させたクロマトグラムを, Fig. 2 に示した. Fig. 2(a) は溶離液がアセトン/水：メタノール=1:1の 結果である. 大勢としては, 逆相吸着に従い低DS（高 OH-) の試料から高DS (低 $\mathrm{OH}^{-}$) の試料の順に溶出し た.しかし、CA-44試料はブロードでピーク割れをお こしており，CA-51 はややブロードピーク，CA-54 と CA-55は, 組成に関係なく溶出した. Fig. 2(b) はアセ トン/水：メタノール =2:1の結果である.CA-44の ピークが異形であるがほぼ組成順に溶出した. Fig. 2(c) はアセトン/水：メタノール=3:1の結果である. 試料 の溶出順位の逆転すなく組成順に溶出し，クロマトグラ ムの形も最す妥当である. Fig. 2(d) はアセトン/水：メ 

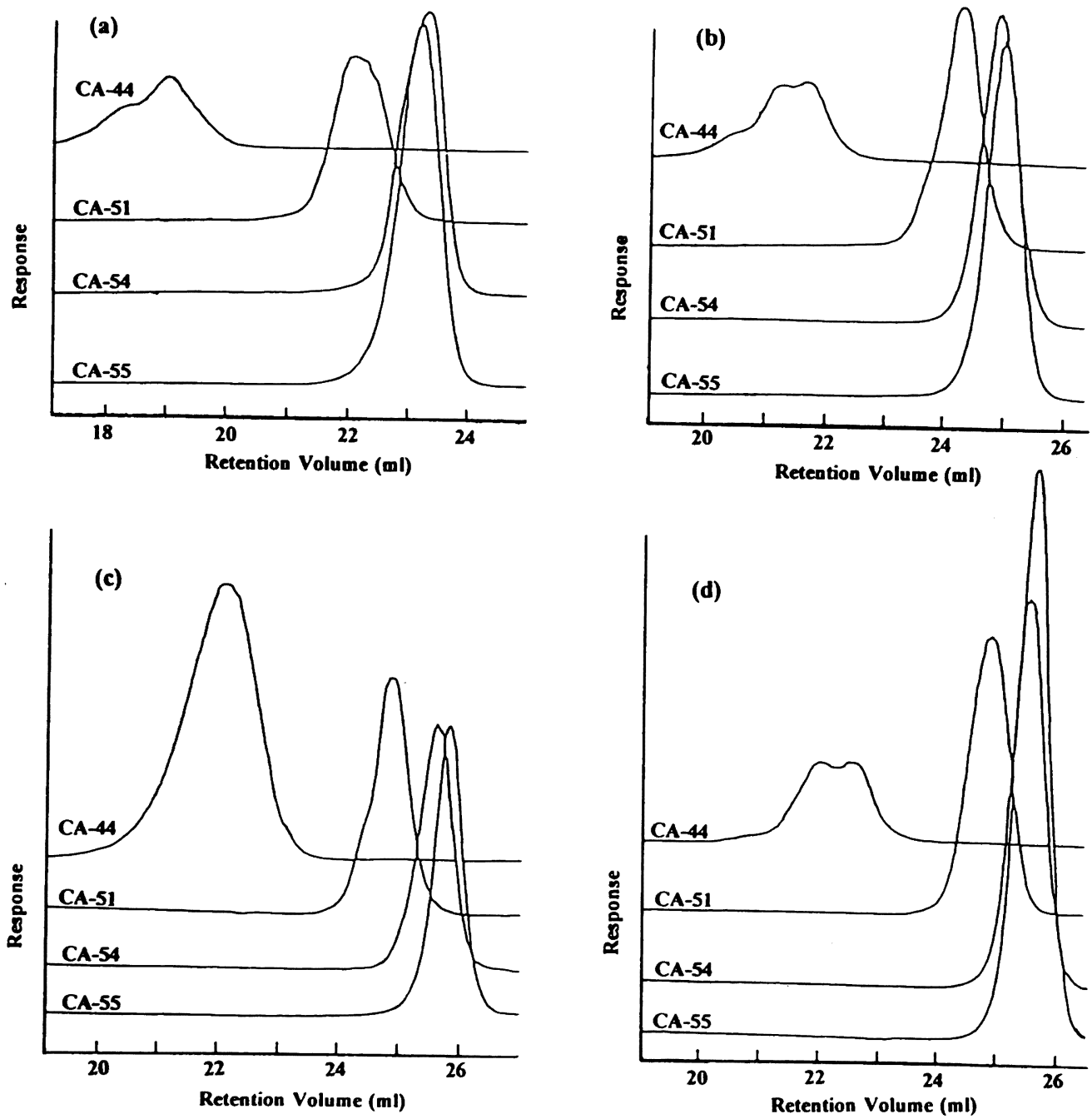

Fig. 2. Chromatograms obtained by the combination of the $\mathrm{Ph}$ column and the gradient elution of acetone/watermethanol. (a) acetone/water : methanol=1:1; (b) acetone/water : methanol =2:1; (c) acetone/water : methanol = $3: 1$; (d) acetone/water : methanol $=4: 1$. In the linear gradient, acetone content was changed from $0 \%$ to $100 \%$ for $30 \mathrm{~min}$.

タノール $=4: 1$ の結果である.CA-44のピークが異形 であるがほぼ組成順に溶出した。 なお, 検出感度は水含 量の增加に従い大きくなった. アセトン/水：メタノー ル=3: 1 が総合的にみて最適と考えられる.

b. $\mathbf{C 1}$ カラムとアセトン/水：メタノール系による組 成分別

テトラメチルシラン修飾シリカゲルを充填したカラム （C1 カラム）とアセトン/水：メタノールの逆相グラジ エント溶出による系の場合, 水：メタノールの比が 3 : 1 では, 逆相吸着に従い, 低 $D S$ (高 $\mathrm{OH}-$ ) 。試料から
高 DS（低 OH-）の試料の順に溶出し，ピークの形にも 異常は認められなかった [Fig. 3(a)].これに対し, 図 には示さなかったが, より水の比率の低い溶離液（水： メタノールの比が 1:1,2:1）およびより高い、水：メ タノール $=4: 1$ ）溶離液を用いた場合には, 溶出順位の 逆転やピークの二山，三山化が見られ，適切な分離が行 われなかった.

c. ODP カラムとアセトン/水：メタノール系による 組成分別

オクタデシル基修飾ポリマーゲルを充媜したカラム 

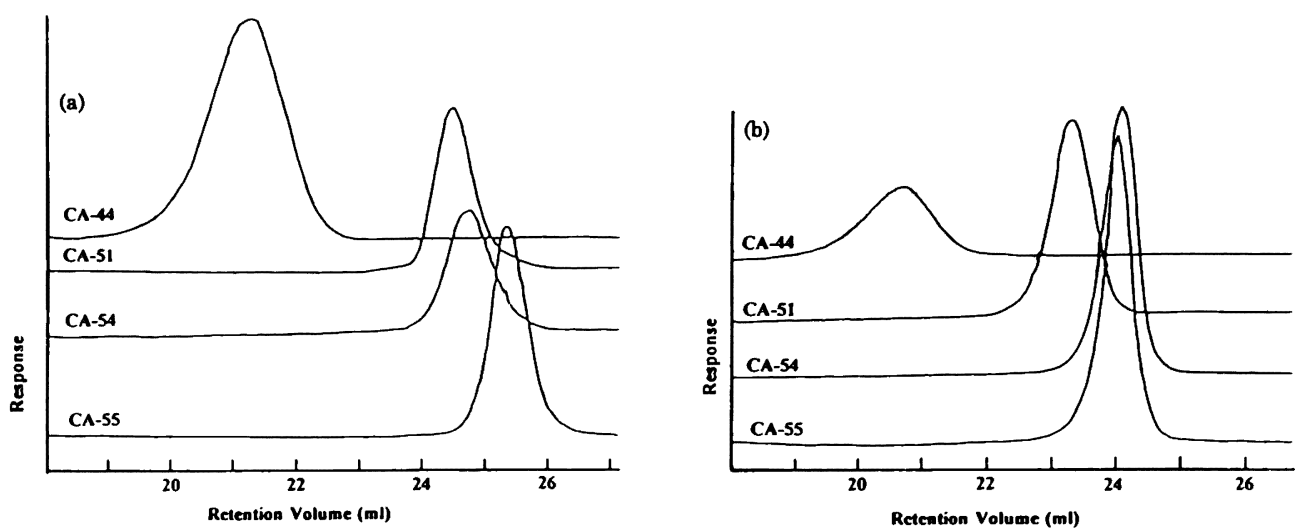

Fig. 3. Chromatograms obtained by the combination of various columns and the gradient elution of acetone/water : methanol=3:1. Column: (a) Zorbax TMS $4.6 \times 250 \mathrm{~mm} 5 \mu \mathrm{m} 70 \AA$; (b) Asahipak ODP $4.6 \times 150 \mathrm{~mm} 6 \mu \mathrm{m} 50 \AA$. In the linear gradient, acetone content was changed from $0 \%$ to $100 \%$ for $30 \mathrm{~min}$.

(a)
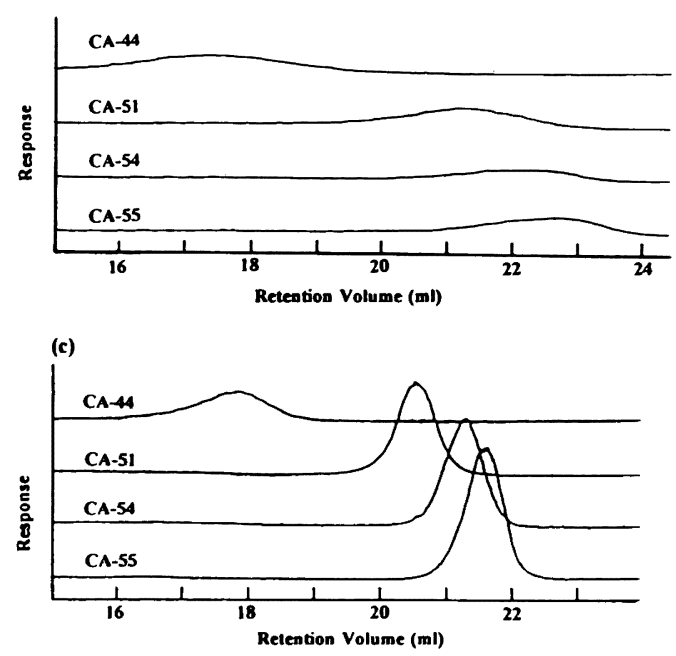

(b)
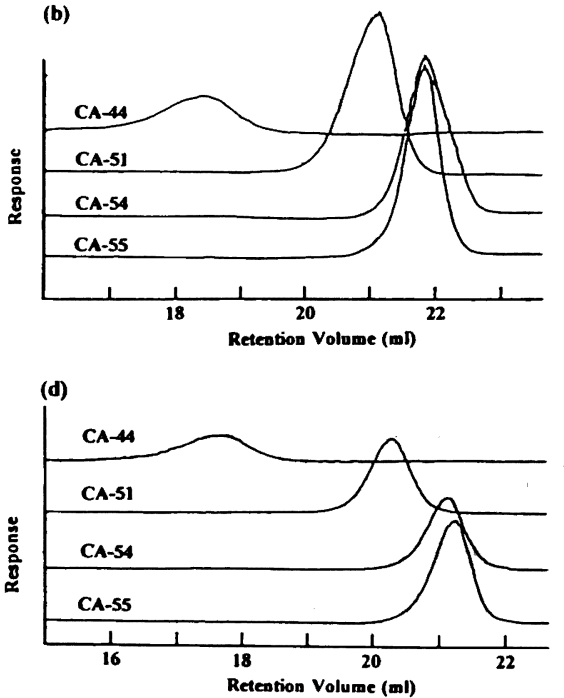

Fig. 4. Chromatograms obtained by the combination of various columns and the gradient elution of THF/water : methanol=3 : 1. Column: (a) Zorbax TMS 4.6 $\times 250 \mathrm{~mm} 5 \mu \mathrm{m} 70 \AA$; (b) $\mu$-Bondasphere Ph 4.6×150 mm $5 \mu \mathrm{m} 100 \AA$; (c) $\mu$-Bondasphere C4 $4.6 \times 150 \mathrm{~mm} 5 \mu \mathrm{m} \mathrm{100A;} \mathrm{(d)} \mathrm{Senshu} \mathrm{Pak} \mathrm{ODS} 4.6 \times 150 \mathrm{~mm} 5 \mu \mathrm{m} 80 \AA$. In the linear gradient, THF content was changed from $0 \%$ to $100 \%$ for 30 min.

（ODPカラム）とアセトン/水：メタノールの逆相グラ ジェント溶出の系の場合でも, 高極性溶離液が水：メ夕 ノール=3:1 の場合 [Fig. 3(b)] が最も妥当な形のクロ マトグラムが得られ, 溶出順位もおおむね妥当であった が, DS の值が近い試料 CA-54 と CA-55 の溶出順位に わずかな逆転が見られた。 むしろ，水：メタノール= $1: 1$ と水: メタノール $=4: 1$ の両極端な系において, 溶出順位は正常で高 $D S$ の分離が良くなっているが，い ずれもピークの形に多山化やひずみが見られた.

\section{d. Ph カラムと THF/水：メタノール系による組成 分別}

上述のように, アセトン/水：メタノールの溶離液で は, Ph力ラムが最も良好な結果を与えたので, Phカラ ムに対して, 溶離液の良溶媒を THFに変えた系を検討 した. 水：メタノールの比によらずピークの形, 溶出順 位とあにほぼ妥当であった，ただし，水：メタノール= $3: 1$ 系では, CA-54 とCA-55 の分離が良くない結果を 与えた.さらに, いずれの溶離液の組み合わせにおいて あ,アセトンを良溶媒として用いた場合と比べて, 検出 
感度が低下した。これは，溶離液の表面張力や粘性，密 度などの影響により，ネブライザーによる微小液滴の大 きさが変化した結果だと考えられる.

e. 種々のカラムと THF/水 : メタノール=3:1系に よる組成分別

$\mathrm{THF} /$ 水: メタノール $=3: 1$ の溶離液を用いて $\mathrm{C} 1$ 力 ラム, Phカラム, ブチル基修飾シリカゲル (C4)カラ ムおよびオクタデシル基修飾シリカゲル (ODS) カラム を用いて得たクロマトグラムを Fig. 4 に示した.
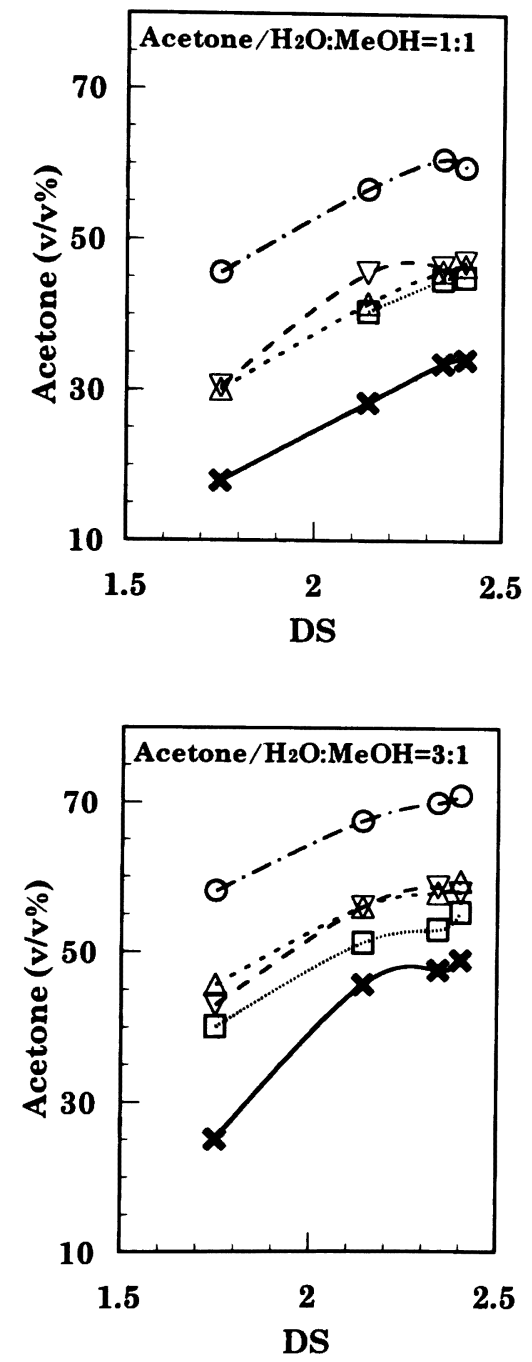

C1 カラム (a)では, 非常に広く低感度なピークしか 検出されなかった．C4 カラムおよび ODS カラムでは， 溶出順位, ピークの形ともに妥当であるが, 検出感度が いくぶん低下した。 また，検出感度が比較的良い $\mathrm{Ph}$ 力 ラムの場合には, 前項 $\mathrm{d}$. で指摘したように, 高 $D S$ 側 で分離が起こっていない。

以上に結果から, 今回検討したカラムと溶離液の組み 合わせの中では, $\mathrm{Ph}$ カラムとアセトン/水 : メタノール $=3: 1$ の組み合わせの系が, 組成分別に用いるのに最
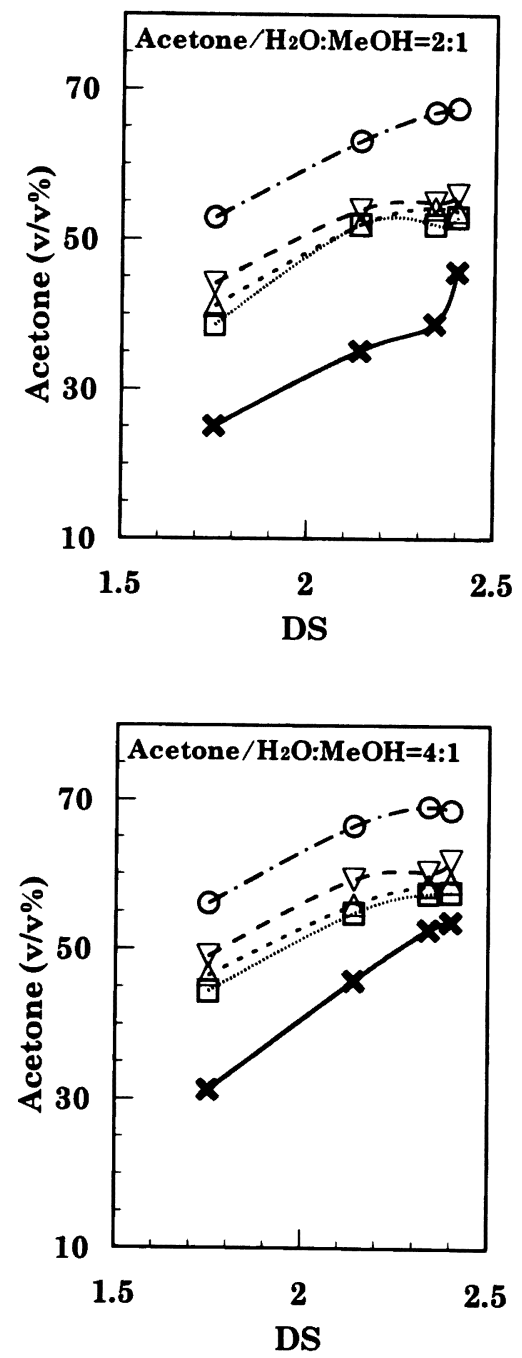

Fig. 5. Relationships between degree of substitution and solvent compositions at the first cloud point and the desorption points by HPLC. (a) acetone/water : methanol=1:1; (b) acetone/water : methanol=2:1; (c) acetone/ water : methanol = $3: 1$; (d) acetone/water : methanol $=4: 1$.

O, $\mu$-Bondasphere Ph $4.6 \times 150 \mathrm{~mm}, 5 \mu \mathrm{m}, 100 \AA ; \nabla$, Asahipak ODP $4.6 \times 150 \mathrm{~mm}, 6 \mu \mathrm{m}, 50 \AA ; \triangle$, Senshu Pak ODS $4.6 \times 150 \mathrm{~mm}, 5 \mu \mathrm{m}, 80 \AA$; $\square$, Zorbax TMS $4.6 \times 250 \mathrm{~mm}, 5 \mu \mathrm{m}, 70 \AA \AA$; , the first cloud point by turbidimetric titration. 

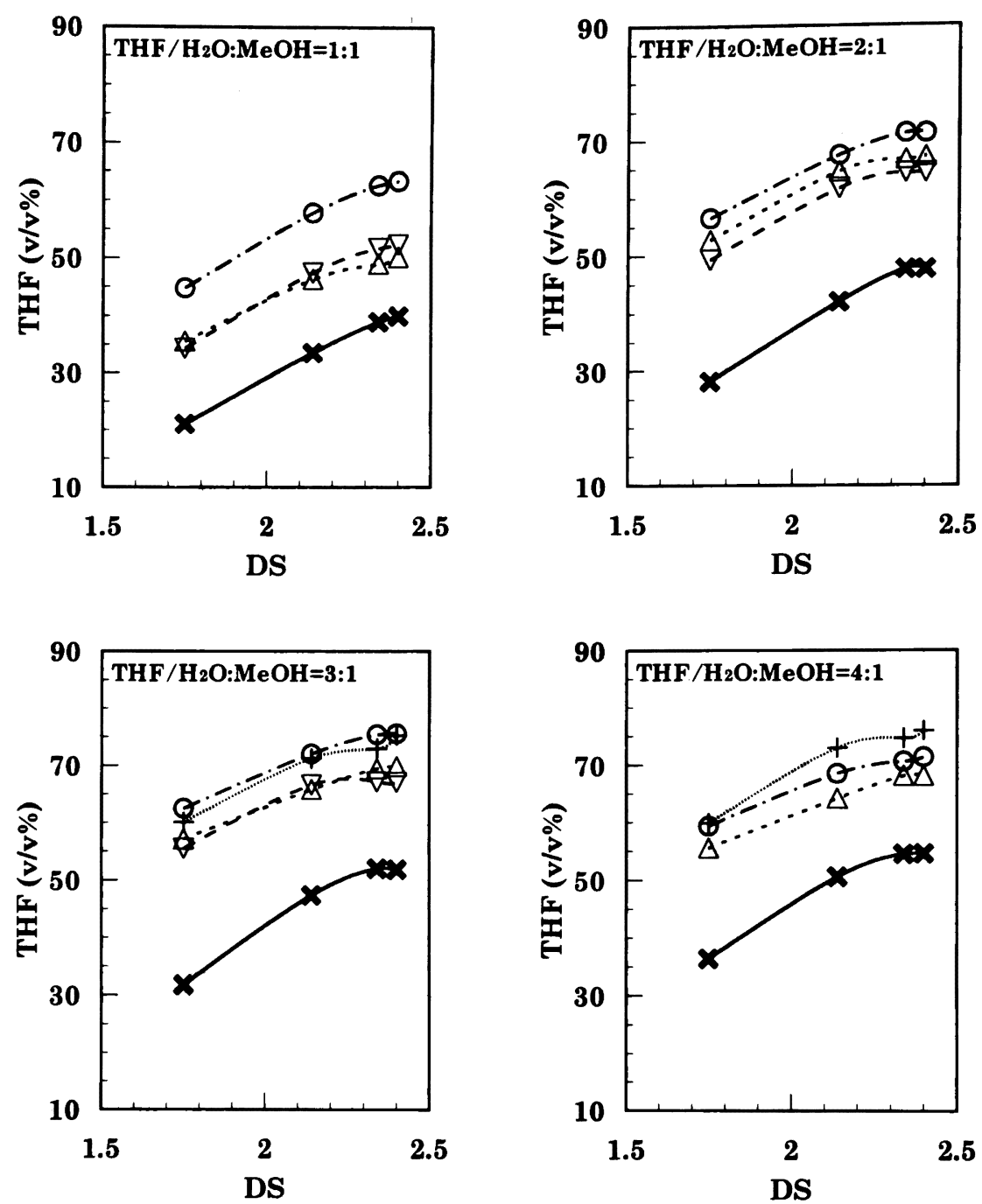

Fig. 6. Relationships between degree of substitution and solvent compositions at the first cloud point and the desorption points by HPLC. (a) THF/water : methanol=1:1; (b) THF/water : methanol=2:1; (c) THF/water : methanol=3:1; (d) THF/water : methanol =4:1.

○, $\mu$-Bondasphere $\mathrm{Ph} 4.6 \times 150 \mathrm{~mm}, 5 \mu \mathrm{m}, 100 \AA ; \nabla$, Asahipak ODP $4.6 \times 150 \mathrm{~mm}, 6 \mu \mathrm{m}, 50 \AA ; \triangle$, Senshu Pak ODS $4.6 \times 150 \mathrm{~mm}, 5 \mu \mathrm{m}, 80 \AA ;+, \mu$-Bondasphere $\mathrm{C} 44.6 \times 150 \mathrm{~mm}, 5 \mu \mathrm{m}, 100 \AA ; X$, the first cloud point by turbidimetric titration.

適であることが分かった.

\section{3 初泟点と溶出ピーク位置の溶媒組成}

良溶媒（低極性溶媒）にそれぞれの試料を溶解した溶 液を非溶媒（高極性混合溶媒=水：メ夕ノール）で滴定 した初濁点における溶媒組成（溶解限界組成）および HPLCによる溶出ピークの溶媒組成（脱離限界組成） を, 試料の DSに対してプロットした図を Fig. 5 と Fig. 6 に示した. いずれの場合も初濁点をつらねた溶解限界
線よりも，脱離限界線が，上り高い良溶媒含率の㑡にあ る.これは, HPLCのグラジェント溶出の過程で, 試 料溶液を非溶媒の流れの中に注入した時に沈殿したポリ マーが, 良溶媒の比率が上昇して溶解してから充填郕表 面に吸着した後, さらに低極性溶媒 (良溶媒) の比率が より高くなって脱離することを示すすのである.した がって，いずれの組み合わせによる分別においても最終 的には，逆相吸着機構による分離が行われていると考え 
逆相吸着 HPLCによるアセチルセルロースの置換度分布の決定

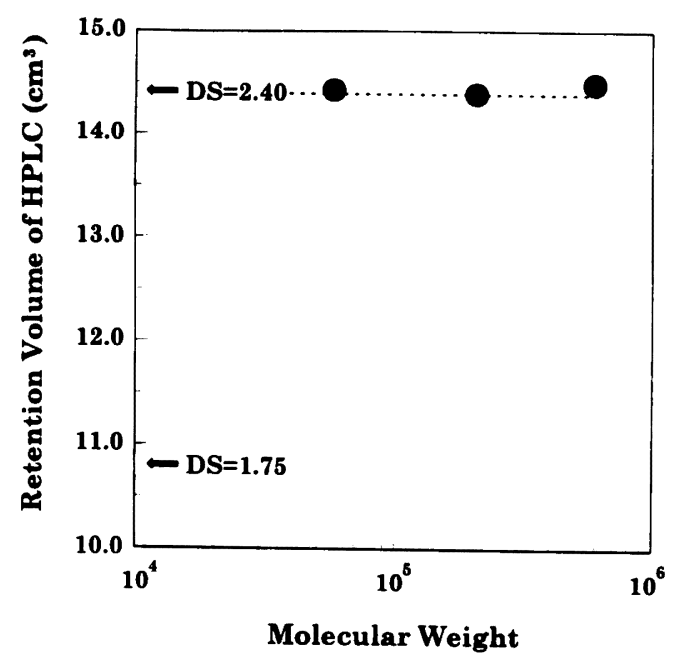

Fig. 7. Relationship between molecular weight and retention volume by HPLC. Sample, fractions of CA-55; column, $\mu$-Bondasphere $\mathrm{Ph} 4.6 \times 150 \mathrm{~mm}, 5$ $\mu \mathrm{m}, 100 \AA$; eluent, acetone/water : methanol $=3: 1$.

られる.

また，低極性溶媒をアセトンとした場合 (Fig. 5) で は，Ph力ラムで最も吸着性が高く，その他のカラムで は, 溶解限界と $\mathrm{Ph}$ カラムでの脱離限界線の中間で溶出 しており，ODP, ODS, C1 の順が見られるとはいえこ れらカラム間の差は小さい，低極性溶媒を THF とした 場合 (Fig. 6)でる，この順序はおおむね保たれている が，アセトンを低極性溶媒とした場合のように $\mathrm{Ph}$ カラ ムの吸着性が特に高いというわけではない。

\section{4 溶出の分子量依存性亡分撂機揞}

溶解機構では，分離に対する分子量の影響は高分子量 領域においてあ避けられないが, 吸着機構での分離にお いては，高分子量領域になれば分子量の影隌は小さく， 無視することができると考えられている. 試料 CA-55 をSECによって分別した区分を Phカラムとアセトン/ 水：メタノール $=3: 1$ の系を用いてグラジェント溶出 し，そのピークの溶出位置と分子量の関係を Fig. 7 に 示した。この結果から明らかなように, 溶出位置は分子 量に関わらずほぼ一定であり, 分子量依存性は無視でき る. 一方, Fig. 5 に示したように,このカラム/溶離液 系においては，逆相吸着機構による組成分離が支配的で ある. それゆえ, 本研究での分離は, 分子間の $D S$ の差 により行われていると考えてよい.

\section{5 クロマトグラムの組成分布への変換}

従来の研究の場合のように, 試料に紫外線吸収があり 溶離液には紫外吸収がない系の場合には，検出に紫外分 光計を用いることができる. しかし，本研究のアセチル セルロースは, 紫外部の吸収をもたないので, 検出器に

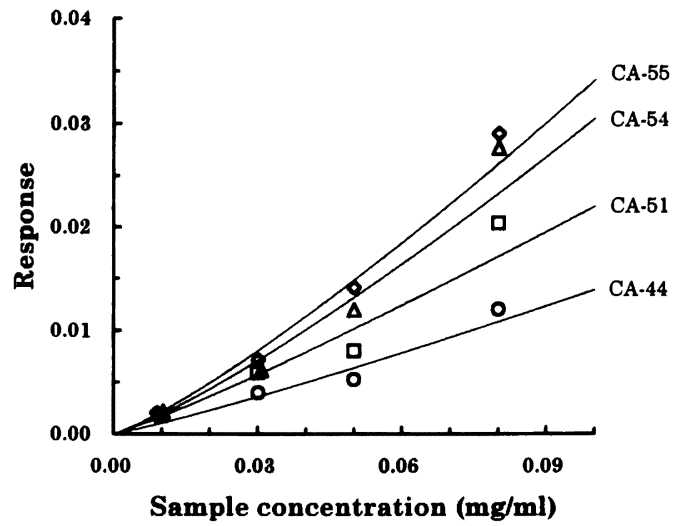

Fig. 8. Relationship between the response by ELSD and the sample concentration. $O$, CA-44; $\square$, CA-51; $\triangle$, CA-54; $\diamond$, CA-55. Column, $\mu$-Bondasphere $\mathrm{Ph}$ $4.6 \times 150 \mathrm{~mm}, 5 \mu \mathrm{m}, 100 \AA$; eluents, acetone/water : methanol=3:1; gas pressure of ELSD, $30 \mathrm{psi}$; drift tube temperature, $150^{\circ} \mathrm{C}$.

は，ELSDを用いたＥLLSDのレスポンスは，粒子浱度 や，粒子径とその分布，粒子の形，表面形態，届折率な ど多くの変数に依存し, 試料浱度に正比例するわけでは ない18)．また，これらの変数は，溶離液組成や試料の組 成に依存する．したがって，グラジェント HPLCで得 られた ELSD のクロマトグラムは, 置換度分布を反映 しているが，そのまま置換度分布であるとはいえない， 定量的な置換度分布を得るためには，各点でのレスポン スを試料浱度に変換するための, 較正方法を工夫する必 要がある. しかし，この試料では，クロマトグラムグラ ムのピーク幅が広く, 各溶出位置では溶媒組成も異な り、レスポンスの浱度に対する依存の仕方す変化するの で，それぞれのピーク内部でも溶出位置により，レスポ ンスと濃度の関係は異なる。このため, 厳密な定量化は 困難であるが、ここでは, 現象論的に次のような手順で クロマトグラムを置換度分布曲線に変換した。

まず, 各々の試料について, 試料の浱度 $(C)$ を变え, クロマトグラムを得た. レスポンス $(R)$ と $C$ の関係は， Fig. 8 に示したように次式で近似できた.

$$
\begin{aligned}
& R=f(D S) \cdot C^{(D S)}, \\
& \log R=g(D S) \times \log C+\log f(D S)
\end{aligned}
$$

これらの係数 $f(D S)$ と指数 $g(D S)$ は, Fig. 9 に示した ように DS 依存性を示し, その依存性は次式で近似でき た.

$$
\begin{aligned}
& f(D S)=0.135 \times D S+0.867 \\
& g(D S)=9.14 \times 10^{-3} \exp (1.67 \times D S)
\end{aligned}
$$

次に, 各試料成分の溶出体積（溶離液組成）とその $D S$ の関係を見積もるために, 各試料のピークトップの 溶出体積 $\left(V_{\mathrm{p}}\right)$ とその平均 $D S_{0}$ との関係を Fig. 10 にプ 


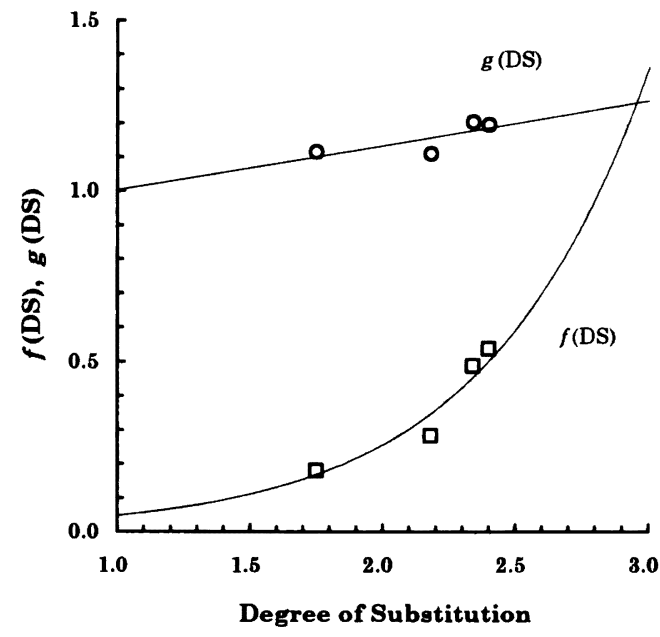

Fig. 9. Relationship between response factors and degree of substitution.

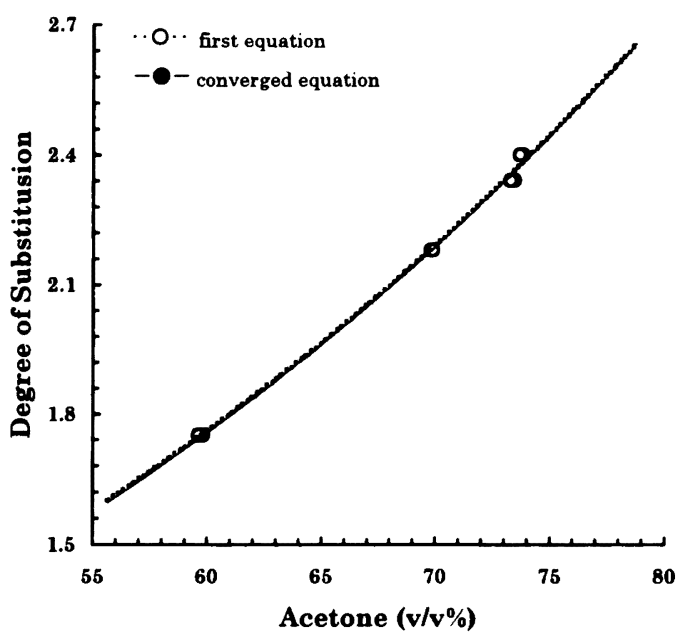

Fig. 10. Calibration curves between eluent composition and degree of substitution. $\cdots . \cdots$, first equation; $\cdots \cdots$, converged equation.

ロットした．この関係は式 (4) で近似できた。

$$
D S_{0}=a_{0} \exp \left(b_{0} \times V_{\mathrm{p}}\right)
$$

しかし，ピークトップの位置に溶出する成分が平均組成 の成分とは限らないので, この式をそのまま $V_{\mathrm{p}}-D S$ 較 正曲線として利用できるわけではない，まず，クロマト グラムのピークを等間隔に細かく区切り, 式 (4) から各 点での溶出位置 $\left(V_{\mathrm{i}}\right)$ における置換度 $\left(D S_{\mathrm{i}}\right)$ を求め, こ の値を用いてその点での $f(D S)$ と $g(D S)$ を式 (2), (3) より求め, その点でのピークの高さ $\left(h_{\mathrm{i}}\right)$ を式 $(5)$ を用 いて相対浱度 $\left(H_{\mathrm{i}}\right)$ に変換する.

$$
H_{\mathrm{i}}=\left(h_{\mathrm{i}} / f\left(D S_{\mathrm{i}}\right)\right)^{\left(1 / 8\left(D S_{\mathrm{i}}\right)\right)}
$$

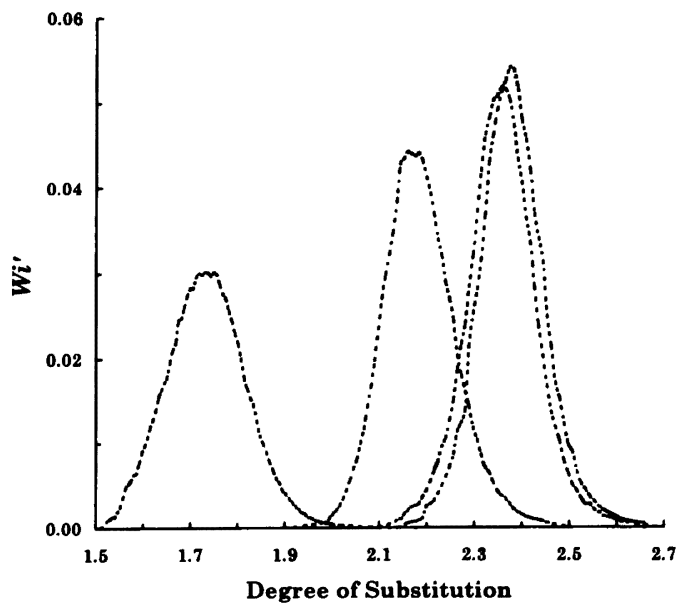

Fig. 11. Degree-of-substitution distribution curves of cellulose acetate samples.

Table 4. Total degree of substitution

\begin{tabular}{ccccc}
\hline \hline Sample & CA-44 & CA-51 & CA-54 & CA-55 \\
\hline Titration method & 1.75 & 2.18 & 2.34 & 2.40 \\
HPLC calibration & 1.75 & 2.19 & 2.35 & 2.38 \\
\hline
\end{tabular}

続いて, 次の関係を用いて,この変換による平均置換度 を求める.

$$
\begin{aligned}
& W_{\mathrm{i}}=H_{\mathrm{i}} / \Sigma H_{\mathrm{i}} \\
& \overline{D S_{\mathrm{I}}}=\Sigma D S_{\mathrm{i}} \times W_{\mathrm{i}}
\end{aligned}
$$

この $\overline{D S}_{1}$ を式 (4) に代入し, 平均置換度に相当する溶 出距離 $\left(V_{1}\right)$ を求める.

この $V_{I}$ と $D S_{0}$ より関係式 (4) と同様の新たな式 (4)' を得る.この (4)' 式を用いて $V_{\mathrm{i}}$ の $D S_{\mathrm{i}}$ への換算を行い 式 (5), (6), (7) により再度 $\overline{D S}_{\mathrm{II}}$ を求める. こうして, 求めた $\overline{D S}_{\mathrm{n}}$ と実測の $D S_{0}$ との差が最も小さくなるまで, この計算を絽り返す. 3 回目の回㷌計算で収束したの で, 得られた式 (Fig. 10 の実線) によって変換された 組成に対して, 最後の式の傾きで補正された重量分率 $W_{\mathrm{i}}^{\prime}$ をプロットして, Fig. 11 の置換度分布曲線を作成し た. 最後に得られた $\overline{D S}$ の值は, Table 4 に示したよう に, 滴定で求められた原試料の值と良く一致している.

\section{6 置換度分布曲缐}

今回の研究で得られた置換度分布曲線は, Fig. 11 に 示したように, 各試料ともに比較的対称性が良く, 全置 換度の減少に伴い置換度分布が広くなる傾向を示した。

今回用いたアセチルセルロース試料は，セルロースを 完全置換体であるトリアセチルセルロースにした後, 目 的の DS になるよう均一系加水分解による脱アセチル化 により合成したものである.このような均一系反応によ 
る場合, 分子鎖内での置換基のシークェンス分布は統計 的であると考えられる. また，グルコースユニット内で の置換基分布に関しても, 均一系での脱アセチル化によ り合成された試料では, 三つの水酸基の間に脱アセチル 化反応の選択性はなく統計的であることが, Miyamoto やKamide らの NMR による研究から明らかにされてい

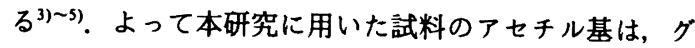
ルコースユニット内であ分子鎖上でも統計的に分布して おり, かつ原試料のトリアセチルセルロースは組成的に 均一なため, 重合度が同程度の試料間で比較をすれば $D S$ の減少に伴いしだいに置換度分布は広がり, $D S=$ 1.5 で最も広い置換度分布を示すと考えられる. 本研究 で用いた試料は，その DS が 1.5 から 3.0 の間のあので あり, また, 分子量と分子量分布はほぼ等しい試料であ るので, DS の減少に伴い置換度分布曲線が広くなると いうこの実験結果は, 妥当なものと考える.

アセチルセルロースの置換度分布について, 上出らは $D S$ が 2.34 から 2.87 の試料を薄層クロマトグラフィー を用い決定している8). 彼らの試料は, $\alpha$ セルロースパ ルプをアセチル化したトリアセチルセルロースの脱アセ チル化により合成したものであるにもかかわらず, その 分布は, 非対称の二山や肩をあつあのであった. この理 由として, 加水分解反応が不均一系で進行したためとし ている. さらに, セルロースパルプを原料としたアセチ ルセルロースは, SECクロマトグラムに二山分布を示 し溶液中でゲル化傾向を示したりすることが報告されて いる ${ }^{19), 20)}$. 今回, 我々が用いた試料では, このような ことはなかった.この相違は, 試料合成の違いによるも のと考えられる.

$$
\text { 文献 }
$$

1) K. Kamide and M. Saito, Macromol. Symp., 83, 233 (1994).
2) 宮本武明，箕田雅彦，高分子，39, 892 (1990).

3) T. Miyamoto, Y. Sato, T. Shibata, M. Takahashi, and $\mathbf{H}$. Inagaki, J. Polym. Sci., Polym. Chem. Ed., 23, 1373 (1985).

4) K. Kowsaka, K. Okajima, and K. Kamide, Polym. J., 20, 827 (1988).

5) C. B. Buchanan, K. J. Edgar, J. A. Hyatt, and A. K. Wilson, Macromolecules, 24, 3050 (1991).

6) A. J. Rosenthal and B. B. White, Ind. Eng. Chem., 44, 2693 (1952).

7) K. Kamide, S. Manabe, and E. Osafune, Makromol. Chem., 168, 173 (1973)

8) K. Kamide, T. Matsui, K. Okajima, and S. Manabe, Cellulose Chem. Technol., 16, 601 (1982).

9) K. Kamide, T. Okada, T. Terakawa, and K. Kaneko, Polym. J., 10, 547 (1978).

10) T. R. Floyd, J. Chromatogr., 629, 243 (1993).

11) S. Teramachi, A. Hasegawa, Y. Shima, M. Akamatsu, and M. Nakajima, Macromolecules, 12, 992 (1979).

12) S. Teramachi, A. Hasegawa, and K. Motoyama, Polym. J., 22, 489 (1990).

13) S. Teramachi, A. Hasegawa, T. Matsumoto, K. Kitahara, Y. Tsukahara, and Y. Yamashita, Macromolecules, 25, 4025 (1992).

14) S. Tanaka, M. Uno, S. Teramachi, and Y. Tsukahara, Polymer, 36, 2219 (1995).

15) S. Teramachi, S. Sato, H. Shimura, S. Watanabe, and Y. Tsukahara, Macromolecules, 28, 6183 (1995).

16) T. Kawai, M. Akashima, and S. Teramachi, Polymer, 36, 2851 (1995).

17) ASTM D871-91

18) G. Glökner, "Gradient HPLC of Copolymers and Chromatographic Cross-Fraction", Springer-Verlag, Berlin (1991).

19) 上出健二, 寺川寿和, 真鍋征一, 螨維学会誌, 30, T464 (1974).

20) 上出健二, 絾維学会誌, 33, P101 (1977).

\section{Determination of Chemical Composition Distributions for Cellulose Acetate by Reversed-Phase High-Performance Liquid Chromatography}

Tadatomo KAwAI*1, ${ }^{\dagger}$, Shinya TeRAMACHI*1, Takahiro SAKAI*1, and Tuyoshi Hibino*1

*1 Department of Applied Chemistry. Faculty of Engineering, Kogakuin University (2665-1 Nakano-cho, Hachioji, Tokyo 192, Japan)

${ }^{\dagger}$ To whom correspondence should be addressed (Tel: (+81)426-22-9291; Fax: (+81)426-28-5647; *E-mail: kawai@sin.cc.kogakuin.ac.jp).

The molecular characterization of cellulose derivatives is very complicated. It is important to determine the distribution of degree of substitution (DS), that is, the intermolecular heterogeneity of the average $D S$ of each molecule (corresponding to the chemical composition distribution of copolymer). Distributions of DS of the acetyl cellulose samples were determined by reversed-phase absorption high-performance liquid chromatography (HPLC). First, the optimum condition for HPLC fractionating the samples according to the $D S$ was investigated using various combinations of columns and eluents. The combination of a phenyl modified silica gel column and liner gradient elution of acetone and mixture of water and methanol ( $3 \mathrm{vs.} 1$ by volume) was found to be more effective than other combinations. The samples were eluted from low acetyl content to high acetyl content, according to reversed-phase adsorption 


\section{川井・寺町・酒井 -日比野}

mechanism. Next, we tried to determine distributions of $D S$ of the samples using this separation system. Since the samples have no UV absorption, evaporative light scattering detector (ELSD) was used for the detection. The response of ELSD does not depend only upon sample concentration. Therefore, the chromatograms were converted to the distributions of $D S$ by the optimization method using calibration curves for concentration and $D S$. The distribution curve of $D S$ thus obtained becomes narrower as the $D S$ increases, in accordance with theoretical consideration.

KEY WORDS Chemical Composition Distribution / Compositional Fractionation /

Reversed-Phase Adsorption HPLC / Cellulose Acetate / Distribution of Degree-of-Substitution / 